\title{
Fluorescence spectroscopy: A tool for the investigation of cheese melting - Correlation with rheological characteristics
}

\author{
Romdhane KAROUI, Arlette LAGUET, Éric DUFOUR* \\ U.R. "Typicité des Produits Alimentaires”, ENITA de Clermont Ferrand, 63370 Lempdes, France
}

(Received 2 May 2002; accepted 31 January 2003)

\begin{abstract}
Trends in the texture and structure as a function of temperature were determined for 2 hard cheeses (Comté and Emmental) and 1 semi-hard cheese (Raclette) using dynamic testing rheology and front-face fluorescence spectroscopy. The storage modulus $\left(\mathrm{G}^{\prime}\right)$, the loss modulus $\left(\mathrm{G}^{\prime \prime}\right)$ and the complex viscosity $\left(\eta^{*}\right)$ decreased while strain and $\tan \delta$ increased as the temperature increased from $5{ }^{\circ} \mathrm{C}$ to $60^{\circ} \mathrm{C}$. Protein tryptophan emission spectra and vitamin A excitation spectra were recorded on cheese samples at $5,10,15,20,25,30,35,40,50$ and $60^{\circ} \mathrm{C}$. For each cheese, the data sets containing fluorescence spectra and rheology data were evaluated using principal component analysis and factorial discriminant analysis. It was shown that the maps defined by principal components 1 and 2 discriminated cheese samples as a function of temperature whatever the data (dynamic testing rheology data or fluorescence spectra). In addition, the melting temperature of fats for the three cheeses determined from the dynamic rheology data and the vitamin A fluorescence spectra gave similar results, i.e., 30,32 and $31{ }^{\circ} \mathrm{C}$ for Emmental, Comté and Raclette cheeses, respectively. Canonical correlation analysis was applied to cheese dynamic rheological measurements and tryptophan and vitamin A fluorescence spectral collections in order to measure the link between the groups of variables measured on the same samples. The rheology and fluorescence groups of variables were found to be highly correlated since the squared canonical coefficients for canonical variables 1 and 2 were higher than 0.94 and 0.49 , respectively.
\end{abstract}

\section{Cheese / structure / texture / melting / fluorescence / rheology}

Résumé - La spectroscopie de fluorescence frontale : un outil pour l'étude de la fonte des fromages - Corrélations avec les données rhéologiques. L'évolution de la texture et de la structure de deux fromages à pâte pressée cuite (Comté et Emmental) et un fromage à pâte pressée non cuite (Raclette) en fonction de la température a été déterminée par des mesures rhéologiques (test d'oscillation) et par spectroscopie de fluorescence frontale. Le module d'élasticité ( $\left.\mathrm{G}^{\prime}\right)$, le module de perte $\left(G^{\prime \prime}\right)$ et la viscosité complexe $\left(\eta^{*}\right)$ diminuent lorsqu'on fait varier la température entre 5 et $60^{\circ} \mathrm{C}$. Cependant, on note un accroissement de la déformation et de la tangente de l'angle de perte, $\tan \delta$, dans la même gamme de température. Les spectres d'émission des tryptophanes de protéines et les spectres d'excitation de la vitamine A ont également été enregistrés sur des échantillons de fromages à $5,10,15,20,25,30,35,40,50$ et $60^{\circ} \mathrm{C}$. Pour chaque type de fromage étudié, les données spectrales (tryptophanes et vitamine A) et les données rhéologiques ont été

* Correspondence and reprints

Tel.: 33.(0)4.73.98.13.78; fax: 33.(0)4.73.98.13.90; e-mail: dufour@enitac.fr 
analysées par analyse en composantes principales et analyse factorielle discriminante, respectivement. La carte factorielle définie par les 2 premières composantes principales a permis de suivre l'évolution des caractéristiques du fromage en fonction de la température appliquée, et ce pour les 2 techniques utilisées. En outre, la température de fusion de la matière grasse des trois types de fromage, déterminée à partir des données rhéologiques et de fluorescence frontale, donne des résultats similaires, soit respectivement, 30,32 et $31^{\circ} \mathrm{C}$ pour l'Emmental, le Comté et la Raclette. L'application de l'analyse canonique des corrélations aux mesures rhéologiques et aux collections spectrales de fluorescence des tryptophanes et de vitamine A a permis de mesurer le lien entre les 2 groupes de variables mesurées sur les mêmes échantillons et a mis en évidence de très fortes corrélations. En effet, les coefficients canoniques au carré pour les variables canoniques 1 et 2 étaient respectivement supérieurs à 0,94 et 0,49 .

Fromage / structure / texture / point de fusion / fluorescence / rhéologie

\section{INTRODUCTION}

Textural properties play a key role in consumer acceptance of cheese $[1,7,19$, 34]. The rheological characterisation of cheeses is important as a means of determining body and texture for quality and identity as a function of composition, processing techniques and storage conditions. It is generally assumed that at room temperature and for a given manufacturing process, milk proteins contribute to firmness and milk fats provide smoothness to cheese: the higher the fat content, the softer the cheese [22]. Moreover, cheese texture may change with the physical state of the fats, depending on temperature [12]. Concomitant with this is a need to characterise cheese behaviour during heating, the change in viscosity and the nature of protein-protein and protein-lipid interactions at elevated temperature. Meltability is one of the most important physical properties of cheese at high temperatures. The melting property of cheese is important not only for texture, but also for the mixing property of cheese in food preparation. It is affected by various technological factors of cheese manufacture such as fat and moisture contents, chymosin level and proteolysis [23, 29].

There are many methods available to study the phenomenon of cheese meltability $[2,25]$. Some methods are based on measuring the change in the diameter or height of a cylindrical cheese sample after heating it in an oven [2]. All these methods are empirical and have a low repeatability. However, dynamic testing methods offer very rapid results with minimal chemical and physical changes [22]. Dynamic low amplitude strain testing refers to the application of a continuously changing stress or strain $[30,33]$. This testing procedure is the most common dynamic method for the study of the viscoelastic behaviour of food $[3,6,8,18,30,31]$.

The melting point of fats and proteinprotein and protein-lipid interactions in cheeses can also be determined by applying front-face fluorescence spectroscopy, which is a sensitive, rapid and non-invasive analytical technique [14, 17]. Indeed, front-face fluorescence spectroscopy can provide information on the presence of fluorescent molecules and their environment, $[14,28]$. Thus, the fluorescence of milk proteins has been used to monitor the structure changes in proteins, and their physico-chemical environment, at two different ripening times [17]. Furthermore, it is possible to monitor the environmental changes of vitamin A trapped in fat globules and the interactions between fat globules and protein. Indeed, due to its conjugated double bonds, vitamin $\mathrm{A}$ is a good fluorescent probe with excitation and emission wavelengths at about 330 and $410 \mathrm{~nm}$, respectively $[10,11]$. 
The purpose of this study was to evaluate the meltability and the viscoelastic behaviour of 2 hard cheeses and 1 semihard cheese using two methods - fluorescence spectroscopy and dynamic testing rheology, in order to discriminate between these cheeses by applying principal component analysis (PCA) and factorial discriminant analysis (FDA) to the whole fluorescence spectra and rheological data. The study serves to show the interest of fluorescence spectroscopy for the investigation of cheese melting and the correlation with rheological characteristics. Indeed, until now information about the relations between rheological measurements and fluorescence spectral data has been lacking. Another objective was to gain some insight into the structure of the cheese matrix and into the relation between the cheese matrix structure and cheese texture using canonical correlation analysis (CCA).

\section{MATERIALS AND METHODS}

\subsection{Cheese samples}

Three different marketed cheeses, 2 hard cheeses (Emmental and Comté) and one semi-hard cheese (Raclette), were purchased in a local supermarket. They were manufactured from raw milk and their duration of ripening was 10 weeks, 5 months and 8 weeks, respectively.

Slices were cut off in the middle of the cheese height $20 \mathrm{~mm}$ from the rind for physico-chemical, rheological and spectroscopic analysis.

\subsection{Physico-chemical analysis}

The determination of $\mathrm{pH}$, dry matter, fat content, total nitrogen and water-soluble nitrogen as protein content for the three cheeses was as described by Bouton et al. [5]. All the analyses were done in dupli- cate. The ripening coefficient was determined as follows:

Ripening coefficient $=100 *$ [watersoluble nitrogen $\left(\mathrm{g} \cdot 100 \mathrm{~g}^{-1}\right) /$ total nitrogen $\left.\left(\mathrm{g} \cdot 100 \mathrm{~g}^{-1}\right)\right]$.

\subsection{Dynamic oscillatory experiments}

Cheeses were sliced into thin disks ( $2 \mathrm{~mm}$ thick and $20 \mathrm{~mm}$ diameter) with a cheese slicer and the sliced samples were placed into plastic bags to prevent dehydration and stored at $5{ }^{\circ} \mathrm{C}$ until analysis. The dynamic oscillatory experiments were performed with a rheometer (CP 20, TA Instrument, Guyancourt, France) with plate geometry of $20 \mathrm{~mm}$ diameter. Oscillation experiments were performed in the linear viscoelastic region by applying a constant force of $0.5 \mathrm{~N}$ and a constant frequency of $1 \mathrm{~Hz}$. All the experiments were carried out at temperatures ranging between 5 and $60{ }^{\circ} \mathrm{C}$ by applying a Peltier plate that provided very accurate and rapid temperature control. In order to select a test condition applicable to all cheese samples, the effect of the duration of the temperature ramp was first investigated for three different times (20 min, $30 \mathrm{~min}$ and $45 \mathrm{~min}$ ). From the results of this preliminary study, a temperature ramp of 30 min was selected, since it allowed an equilibration of the thin cheese samples, to obtain reproducible results and a discrimination of the different cheeses investigated.

The data obtained included the two components of shear modulus $\mathrm{G}^{*}$, i.e., the elastic component $\mathrm{G}^{\prime}$ (storage modulus) and the viscous component $G^{\prime \prime}$ (loss modulus). The complex viscosity $\left(\eta^{*}\right), \tan \delta$ and the strain were also measured. Data were recorded every $0.4{ }^{\circ} \mathrm{C}$ between 5 and $60^{\circ} \mathrm{C}$ (number of points $=136$ ). For each cheese, five curves were recorded using different samples. Any slippage was detected for all the experiments. Plots of $\log \left(\eta^{*}\right)$ versus temperature were obtained for the investigated cheeses. They showed two distinct linear regions and the intersection point 
was identified as the melting point of fats in the cheese.

\subsection{Fluorescence spectroscopy}

Fluorescence spectra were recorded using a FluoroMax-2 spectrofluorimeter (Spex-Jobin Yvon, Longjumeau, France). The incidence angle of the excitation radiation was set at $56^{\circ}$ to ensure that reflected light, scattered radiation and depolarisation phenomena were minimised. The spectrofluorimeter was equipped with a thermostated cell and the temperature was controlled by a Haake temperature controller (Haake, Champlan, France). Slices of $2 \mathrm{~cm}$ length, $2 \mathrm{~cm}$ width and $0.2 \mathrm{~cm}$ thickness were cut off in the middle of the cheese height $20 \mathrm{~mm}$ from the rind. Spectra of cheese samples $(2 \mathrm{~cm} \times 1 \mathrm{~cm} \times$ $0.2 \mathrm{~cm}$ ) mounted between two quartz slides were recorded at 5, 10, 15, 20, 25, $30,35,40,50$ and $60{ }^{\circ} \mathrm{C}$. For each cheese, three kinetics were performed using different samples, and for each temperature three spectra were recorded. The sample is illuminated by the photons of excitation (light beam: $\sim 3 \mathrm{~mm}$ in height $\times \sim 0.3 \mathrm{~mm}$ width) in its centre, limiting the dehydration of the sample. Between the acquisition of spectra at 2 different temperatures, the temperature of the cheese sample was equilibrated for $10 \mathrm{~min}$. The emission spectra of tryptophan residues $305-400 \mathrm{~nm}$ (increment: $0.5 \mathrm{~nm}$, which corresponded to 192 points of measurement) were recorded with the excitation wavelength set at $290 \mathrm{~nm}$ and the excitation spectra of vitamin A 250-350 nm (increment: $1 \mathrm{~nm}$, which corresponded to 100 points of measurement) were recorded with the emission wavelength set at $410 \mathrm{~nm}$. All spectra were corrected for instrumental distortions in excitation using a rhodamine cell in the reference channel.

30 spectra of tryptophan residues and 30 spectra of vitamin A were collected for each cheese.

\subsection{Mathematical treatment of data}

\subsubsection{Principal component analysis}

In order to reduce scattering effects, the fluorescence spectra were normalised by reducing the area under each spectrum to a value of 1 according to Bertrand and Scotter [4]. PCA was applied to the rheological data and to the normalised spectra in order to investigate changes in the data [15, 16]. This statistical multivariate treatment makes it possible to draw similarity maps of the samples and to get spectral patterns [4, 20]. While the similarity maps allow the comparison of the spectra in such a way that two neighbouring points represent two similar spectra, the spectral patterns exhibit the absorption bands that explain the similarities observed on the maps.

\subsubsection{Factorial discriminant analysis}

The ability of the data to describe the 3 kinds of cheeses was investigated by applying discriminant analysis to the first 10 principal components of the PCA performed on the rheological data. A group was created for each type of cheese. From the first 10 principal components selected, factorial discriminant analysis (FDA) assessed new synthetic variables called discriminant factors, which were not correlated and allowed the best separation of the qualitative groups. Similarity maps can be drawn, in analogy to those for PCA.

\subsubsection{Correlation between two sets of data}

The fluorescence spectral data and the rheological data were further analysed using canonical correlation analysis (CCA), a multivariate treatment that describes the correlation between two sets of data [32]. CCA was carried out with the Statgraphics Plus Program (Statistical Graphics Corp., Englewood Cliffs, NJ, USA). 
Table I. Physico-chemical composition (mean and standard deviation) of the investigated cheeses.

\begin{tabular}{|c|c|c|c|}
\hline Parameters & Mean & SD* & $\mathrm{CV}^{*}$ \\
\hline \multicolumn{4}{|c|}{ Emmental cheese } \\
\hline $\mathrm{pH}$ & 5.90 & 0.00 & 0.00 \\
\hline Fat $(\%)$ & 30.13 & 0.18 & 0.59 \\
\hline Dry matter (\%) & 64.30 & 0.27 & 0.42 \\
\hline Fat in dry matter $(\%)$ & 46.85 & 0.08 & 0.17 \\
\hline $\mathrm{TN}^{*}\left(\mathrm{~g} \cdot 100 \mathrm{~g}^{-1}\right)$ & 4.14 & 0.02 & 0.56 \\
\hline $\mathrm{WSN} * / \mathrm{TN}(\%)$ & 15.25 & 0.30 & 1.97 \\
\hline \multicolumn{4}{|c|}{ Comté cheese } \\
\hline pH & 5.91 & 0.01 & 0.12 \\
\hline Fat $(\%)$ & 33.75 & 0.00 & 0.00 \\
\hline Dry matter $(\%)$ & 65.06 & 0.06 & 0.09 \\
\hline Fat in dry matter $(\%)$ & 51.88 & 0.05 & 0.09 \\
\hline $\mathrm{TN}^{*}\left(\mathrm{~g} \cdot 100 \mathrm{~g}^{-1}\right)$ & 4.16 & 0.07 & 1.70 \\
\hline $\mathrm{WSN} * / \mathrm{TN}(\%)$ & 22.72 & 0.45 & 2.00 \\
\hline \multicolumn{4}{|c|}{ Raclette cheese } \\
\hline $\mathrm{pH}$ & 5.88 & 0.01 & 0.12 \\
\hline Fat $(\%)$ & 29.50 & 0.00 & 0.00 \\
\hline Dry matter $(\%)$ & 57.65 & 0.07 & 0.13 \\
\hline Fat in dry matter $(\%)$ & 51.17 & 0.06 & 0.13 \\
\hline $\mathrm{TN}^{*}\left(\mathrm{~g} \cdot 100 \mathrm{~g}^{-1}\right)$ & 3.41 & 0.06 & 1.66 \\
\hline WSN*/TN (\%) & 30.48 & 1.92 & 6.31 \\
\hline
\end{tabular}

* SD: standard deviation; CV: $100 \times(\mathrm{SD} /$ mean $)$; TN: total nitrogen; WSN: water-soluble nitrogen.

\section{RESULTS AND DISCUSSION}

\subsection{Physico-chemical characterisation of cheeses}

The results for $\mathrm{pH}$, fat, fat in dry matter, total nitrogen and water-soluble nitrogen determinations for the 3 cheeses are reported in Table I. On the one hand, the fat content in Comté cheese was higher than in Emmental and Raclette cheeses. The results of a Student test showed that a significant difference was observed between fat content and fat in dry matter of the three cheeses $(P<0.05)$. On the other hand, no significant difference was observed for the $\mathrm{pH}$ of the three cheeses. The Raclette cheese had a lower dry matter than Comté and Emmental cheeses, which exhibited similar values for this parameter. This difference may be explained by the fact that hard cheeses undergo cooking $\left(53-55^{\circ} \mathrm{C}\right)$ for 30 to 60 min during work in the tank, in order to carry out a more extensive drainage to reach a final dry extract from 60 to $65 \%$, which is in agreement with our results. The ripening coefficient of the Raclette cheese $(30.48 \% \pm 1.92)$ was drastically higher than those of Emmental $(15.25 \% \pm 0.3)$ and Comté $(22.72 \% \pm 0.45)$ cheeses. This can be explained by the differences related to the milk composition, manufacturing process and ripening parameters, which have an effect on the nature and the intensity of proteolysis $[9,21]$.

\subsection{Dynamic rheological measurements}

For the 3 cheeses, G', G" (Tab. II) and $\eta^{*}$ (data not shown) decreased, but $\tan \delta$ and strain increased (data not shown) when the temperature increased. This result was in agreement with Rosenberg et al. [30] who report that $G^{\prime}$ is affected by the temperature, the frequency and the cheese age. This can be attributed to the effect of temperature on protein-protein and proteinwater interactions $[13,30]$. In addition, the decrease in the temperature induces an increase in the yield of milk fat in the solid state and, as a consequence, results in an increase in $G^{\prime}$ and $G^{\prime \prime}[13,27]$. From Table II, it appears that during the increase in temperature, Emmental cheese presented a less marked character of the "liquid type" since it is the firmest and the most rubbery cheese. Indeed, whatever the temperature, Emmental cheese exhibited the highest values of $G^{\prime}$ and $G^{\prime \prime}$, whereas Comté cheese showed the lowest ones at $20,25,30,35,40,50$ and $60{ }^{\circ} \mathrm{C}$ (Tab. II). These differences may be explained by the 
Table II. Rheological parameters (G', G") measured for the three cheeses at 5, 10, 15, 20, 25, 30, $35,40,50$ and $60^{\circ} \mathrm{C}$.

\begin{tabular}{|c|c|c|c|c|c|c|}
\hline \multirow[b]{3}{*}{$\begin{array}{l}\text { Temperature } \\
\left({ }^{\circ} \mathrm{C}\right)\end{array}$} & \multicolumn{6}{|c|}{$\mathrm{G}^{\prime}(\mathrm{Pa})$} \\
\hline & \multicolumn{2}{|c|}{ Emmental } & \multicolumn{2}{|c|}{ Comté } & \multicolumn{2}{|c|}{ Raclette } \\
\hline & Mean & SD* & Mean & $\mathrm{SD}^{*}$ & Mean & SD* \\
\hline 5 & $159.4610^{3}$ & $27.7110^{3}$ & $120.1810^{3}$ & $15.9010^{3}$ & $103.1010^{3}$ & $9.9910^{3}$ \\
\hline 10 & $146.2810^{3}$ & $13.5410^{3}$ & $107.7710^{3}$ & $19.3910^{3}$ & $102.5210^{3}$ & $11.7510^{3}$ \\
\hline 15 & $87.4810^{3}$ & $9.1210^{3}$ & $68.6810^{3}$ & $12.4610^{3}$ & $76.5810^{3}$ & $7.2610^{3}$ \\
\hline 20 & $56.6810^{3}$ & $5.6910^{3}$ & $47.1910^{3}$ & $10.1410^{3}$ & $56.2010^{3}$ & $4.2110^{3}$ \\
\hline 25 & $39.6610^{3}$ & $3.7610^{3}$ & $33.0310^{3}$ & $8.5410^{3}$ & $39.0810^{3}$ & $3.3210^{3}$ \\
\hline 30 & $27.5510^{3}$ & $2.1210^{3}$ & $21.8010^{3}$ & $7.0810^{3}$ & $26.3610^{3}$ & $2.3410^{3}$ \\
\hline 35 & $17.3710^{3}$ & $1.2510^{3}$ & $12.8310^{3}$ & $5.1310^{3}$ & $16.3510^{3}$ & $1.1810^{3}$ \\
\hline 40 & $11.5210^{3}$ & $0.6610^{3}$ & $7.6010^{3}$ & $3.5310^{3}$ & $10.0610^{3}$ & $0.7010^{3}$ \\
\hline 50 & $4.6310^{3}$ & $0.7110^{3}$ & $1.5710^{3}$ & $0.8510^{3}$ & $3.1210^{3}$ & $0.3910^{3}$ \\
\hline \multirow[t]{3}{*}{60} & $1.3510^{3}$ & $0.1810^{3}$ & $0.3610^{3}$ & $0.0910^{3}$ & $1.0310^{3}$ & $0.1310^{3}$ \\
\hline & \multicolumn{6}{|c|}{$\mathrm{G}^{\prime \prime}(\mathrm{Pa})$} \\
\hline & \multicolumn{2}{|c|}{ Emmental } & \multicolumn{2}{|c|}{ Comté } & \multicolumn{2}{|c|}{ Raclette } \\
\hline $\begin{array}{l}\text { Temperature } \\
\left({ }^{\circ} \mathrm{C}\right)\end{array}$ & Mean & $\mathrm{SD}^{*}$ & Mean & SD* & Mean & $\mathrm{SD}^{*}$ \\
\hline 5 & $54.6010^{3}$ & $8.6710^{3}$ & $40.6710^{3}$ & $2.8510^{3}$ & $32.9610^{3}$ & $2.8110^{3}$ \\
\hline 10 & $49.6610^{3}$ & $5.2010^{3}$ & $35.6710^{3}$ & $4.3910^{3}$ & $31.3210^{3}$ & $2.9810^{3}$ \\
\hline 15 & $32.3010^{3}$ & $3.8410^{3}$ & $24.5010^{3}$ & $2.7210^{3}$ & $24.0910^{3}$ & $1.5510^{3}$ \\
\hline 20 & $21.5610^{3}$ & $2.4610^{3}$ & $17.3910^{3}$ & $2.5210^{3}$ & $18.0810^{3}$ & $0.8910^{3}$ \\
\hline 25 & $15.2510^{3}$ & $1.5810^{3}$ & $12.6010^{3}$ & $2.4010^{3}$ & $13.1610^{3}$ & $0.8510^{3}$ \\
\hline 30 & $11.0310^{3}$ & $0.9910^{3}$ & $8.9110^{3}$ & $2.3110^{3}$ & $9.3310^{3}$ & $0.6510^{3}$ \\
\hline 35 & $7.5910^{3}$ & $0.6310^{3}$ & $5.9110^{3}$ & $2.0310^{3}$ & $6.2810^{3}$ & $0.4110^{3}$ \\
\hline 40 & $5.4810^{3}$ & $0.4110^{3}$ & $3.9610^{3}$ & $1.6110^{3}$ & $4.3810^{3}$ & $0.2910^{3}$ \\
\hline 50 & $3.1510^{3}$ & $0.3710^{3}$ & $1.1910^{3}$ & $0.5410^{3}$ & $2.1210^{3}$ & $0.2610^{3}$ \\
\hline 60 & $1.4610^{3}$ & $0.1210^{3}$ & $0.4410^{3}$ & $0.1010^{3}$ & $1.0210^{3}$ & $0.1210^{3}$ \\
\hline
\end{tabular}

SD*: standard deviation.

characteristics of the protein network and the gross composition of the cheese. The lowest values of $\mathrm{G}^{\prime}$ and $\mathrm{G}^{\prime \prime}$ of Comté cheese at high temperatures could be related to the amount of fat. Indeed, at high temperatures, the stiffness decreases with the amount of fat [35].
Delta equal to $45^{\circ}$ of angle $(\tan \delta=1)$ indicates the temperature where the viscous properties prevail, i.e., the cheese starts to melt [13]. For Comté cheese, this temperature was observed at $55^{\circ} \mathrm{C}$, while temperatures of 58 and $60{ }^{\circ} \mathrm{C}$ were obtained for Emmental and Raclette 


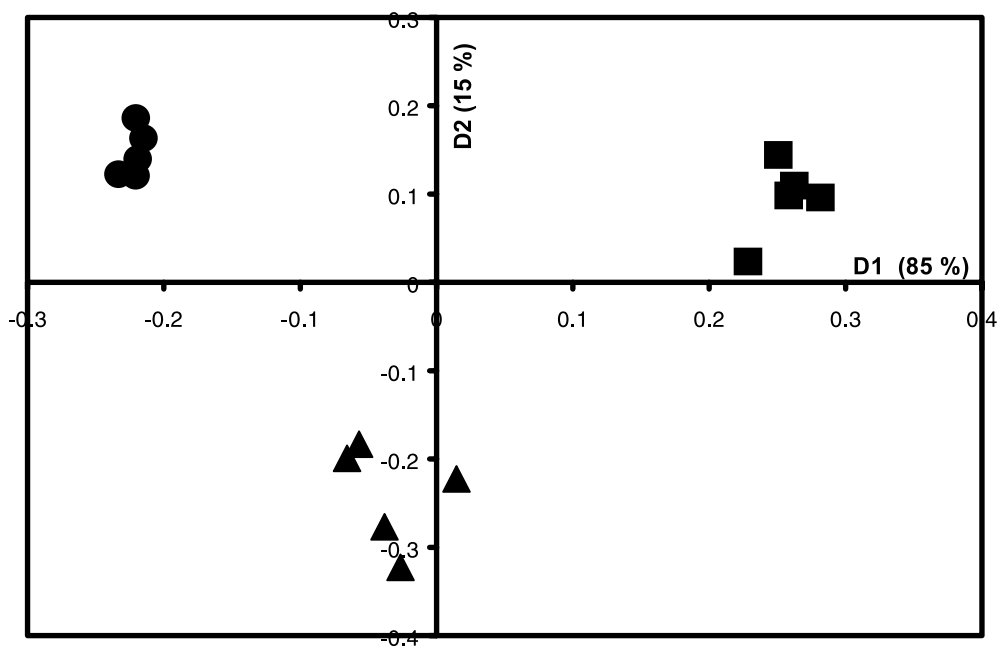

Figure 1 : Discriminant analysis similarity map determined by discriminant functions 1 and 2 for the rheological data $\left(G^{\prime}, G^{\prime \prime}, \tan \delta\right.$, strain and $\left.\eta^{*}\right)$ of the three cheeses at a temperature ranging between 5 and $60{ }^{\circ} \mathrm{C}:(\boldsymbol{\Delta})$ : Raclette; $(\bullet)$ : Comté; $(\boldsymbol{\square})$ : Emmental.

cheeses, respectively (data not shown). This result is in agreement with [13] reporting that the melting point of Emmental cheese is in the $55-60{ }^{\circ} \mathrm{C}$ temperature range.

In a second step, PCA was applied to the rheology data $\left(\mathrm{G}^{\prime}, \mathrm{G}^{\prime \prime}, \tan \delta\right.$, strain and $\left.\eta^{*}\right)$ of Emmental cheese in order to investigate changes in the data in the $5-60{ }^{\circ} \mathrm{C}$ temperature range. The data matrix included 5 variables (rheological data) and 136 objects (temperatures). The PCA results showed that the first two principal components took into account $99.7 \%$ of the total variance with a large predominance of principal component $1(85.1 \%)$, discriminating the samples as a function of temperature (data not shown). The rheological values recorded at low temperature had positive scores according to the principal component 1 , whereas negative scores were observed for the ones recorded at high temperatures. Similar results were obtained on the two other cheeses.

Finally, the rheological data recorded during the temperature increase for the three cheeses ( 5 repetitions of each type of cheese) were pooled in one matrix and this table was analysed in a first step by PCA and then FDA was performed on the first 10 principal components of the PCA. The data matrix for FDA included 15 objects and 10 variables (the first 10 principal components). The first two discriminant factors took into account $85 \%$ and $15 \%$ of the total variance, respectively, and the map defined by discriminant factors 1 and 2 showed that the data were well suited for the discrimination of the 3 cheeses (Fig. 1). A discrimination of samples of Emmental cheese from Raclette and Comté cheeses was essentially observed according to the discriminant factor 1. Emmental cheeses, exhibiting the highest values of G' (Tab. II), were on the positive side. The discriminant factor 2 mainly discriminated Comté and Emmental cheeses from Raclette cheese.

\subsection{Evolution of tryptophan and vitamin A fluorescence properties}

The tryptophan emission spectra of the three commercial cheeses presented a maximum located at about $330 \mathrm{~nm}$, and it 


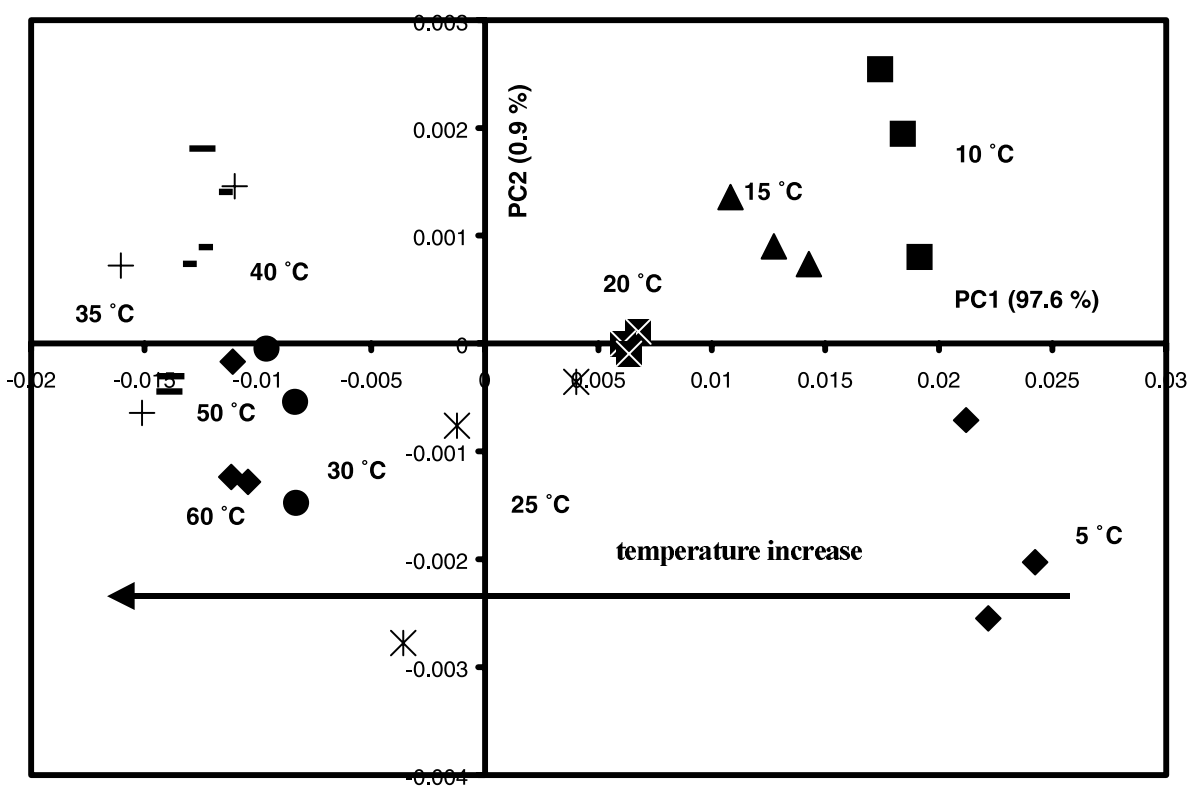

Figure 2. Principal component analysis similarity map determined by principal components 1 and 2 for tryptophan spectra of Emmental cheese at different temperatures.

appeared that the shape of the fluorescence spectra of tryptophan at $60{ }^{\circ} \mathrm{C}$ was larger than those at $5{ }^{\circ} \mathrm{C}$ and $30^{\circ} \mathrm{C}$, whatever the cheese. In addition, the maximum emission shifted with temperature, i.e., the maxima located at $330 \mathrm{~nm}$ and $340 \mathrm{~nm}$ were observed at $5{ }^{\circ} \mathrm{C}$ and $60{ }^{\circ} \mathrm{C}$, respectively.

The excitation spectra of vitamin A were characterised by a maximum located at $322 \mathrm{~nm}$ and two shoulders at 305 and $295 \mathrm{~nm}$. The shape of the spectra changed drastically with the increase of temperature (data not shown). The $F 322 \mathrm{~nm} / F 295 \mathrm{~nm}$ ratio exhibited differences from one cheese to another, but it decreased with the increase in temperature for all the investigated cheeses. It is explained by the decrease in the viscosity of triglycerides with the temperature increase. Indeed, it has been shown that the fluorescent properties of fluorophores are very sensitive to the changes in the solvent viscosity [10-12].

As the fluorescence spectra of the three cheeses exhibited slight differences, uni- variate analysis was not really appropriate for the study of large data sets. Multivariate analysis techniques, such as PCA, FDA and CCA make it possible to extract information related to the structural changes in cheeses from the fluorescence spectra [32].

First, PCA was applied to the set (30 objects and 192 variables) of tryptophan fluorescence spectra recorded on Emmental cheese. The first two principal components accounted for $98.5 \%$ of the total variance with a large predominance of the principal component 1 (97.6\%). It appeared that spectra recorded at temperatures below $20^{\circ} \mathrm{C}$ exhibited positive scores according to the first principal component, whereas those recorded at 25, 30, 35, 40, 50 and $60{ }^{\circ} \mathrm{C}$ exhibited negative scores (Fig. 2). Although samples were close to each other at $30,35,40,50$ and $60^{\circ} \mathrm{C}$, a different trend was observed for the tryptophan spectra recorded at $5,10,15,20$ and $25^{\circ} \mathrm{C}$. These differences could be explained by the change in the structure of 
proteins, the physical state of triglycerides and protein-lipid interactions.

Spectral pattern 1 (data not shown) indicated that the shape of fluorescence spectra was larger at high temperatures than at low temperatures. It agrees with a broader diversity of the environments of tryptophan residues in the cheese matrix at high temperatures. These spectral differences have to be related to the changes in proteinprotein and protein-lipid interactions and to the different network structures resulting from cheese melting $[15,17,28]$. Similar results were obtained following the analysis of Comté and Raclette cheese spectra recorded in the $5-60{ }^{\circ} \mathrm{C}$ temperature range.

Secondly, PCA was applied to the set (30 objects and 100 variables) of vitamin A fluorescence spectra recorded on Emmental cheese, and the map defined by principal components 1 and 2 took into account $98.6 \%$ and $0.9 \%$ of the total variance (data not shown), respectively, and discriminated the samples according to temperature. The trend observed for vitamin A spectra is close to that observed for tryptophan data. The principal component 1 that explained most of the total inertia of the spectral data allowed the discrimination of the spectra according to temperature. The examination of spectral pattern 1 (data not shown) showed an opposition between a positive peak at $275 \mathrm{~nm}$ and a negative peak at $324 \mathrm{~nm}$. This pattern has been reported previously [12] and agrees with the change in the physical state of triglycerides. Similar results were obtained following the analysis of the vitamin A fluorescence spectra of Comté and Raclette cheeses in the $5-60{ }^{\circ} \mathrm{C}$ temperature range. It suggests that vitamin $\mathrm{A}$ is a valuable probe for investigating the melting of cheeses in general, and of the fats in cheeses in particular.

Finally, the tryptophan fluorescence spectra recorded between 5 and $60{ }^{\circ} \mathrm{C}$ for the 3 cheeses were pooled in one matrix including 90 objects and 192 variables. A similar matrix (90 objects and 100 varia- bles) was built from the vitamin A spectra. Considering the maps defined by the principal components 1 and 2 of the PCA performed on the two data sets, a better discrimination of the three cheeses was observed for the tryptophan fluorescence data. The map defined by the principal components 1 and 2 took into account $86.2 \%$ and $12.8 \%$ of the total variance, respectively, and showed quite a good discrimination of Comté cheese from Raclette and Emmental cheeses according to the principal component 1 (Fig. 3). In addition, a discrimination of the spectra of Emmental cheese at $5,10,15,20$ and $25^{\circ} \mathrm{C}$ from those of Comté cheese was observed according to the second principal component. The examination of the spectral pattern 1 indicated that the shape of fluorescence spectra was larger for the spectra with negative scores than those with positive scores. It agrees with a broader diversity of the environments of tryptophan residues in the cheese matrix at high temperatures. It was concluded that the increase in the temperature induced specific modifications in the shape of the fluorescence spectra [10] and that tryptophan and vitamin A fluorescence spectra allowed discrimination between Raclette, Comté and Emmental cheeses during melting. These results clearly indicate that the structures of the cheeses at a molecular level as measured by fluorescence are related to the manufacturing processes and the melting properties of the 3 investigated cheeses.

\subsection{Determination of the melting temperatures of fats in the 3 cheeses from the rheology and fluorescence data}

Table III reports the melting points of the fats in the three cheeses derived from rheology data and fluorescence spectra. Considering the rheology data, a significant difference was observed between the data obtained from Emmental cheese and the two other cheeses at a level effect of $5 \%$. 


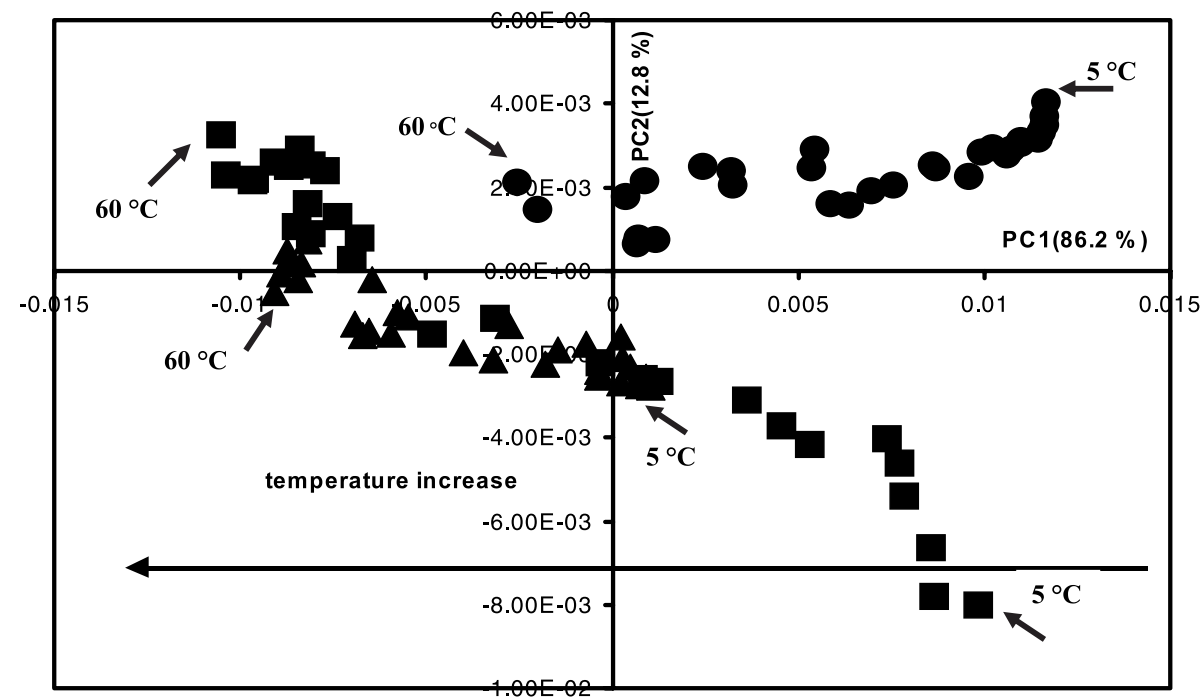

Figure 3. Principal component analysis similarity map determined by principal components 1 and 2 for the tryptophan spectra of the three cheeses at different temperatures: (ム): Raclette; $(\bullet)$ : Comté; (匹): Emmental.

Considering fluorescence, it has been reported that the melting temperature of fats in a model emulsion can be derived by plotting $F 322 \mathrm{~nm} / F 295 \mathrm{~nm}$ versus temperature [26]. From the spectral data of vitamin A, typical plots of the $F 322 \mathrm{~nm} /$ $F 295 \mathrm{~nm}$ ratio versus temperature were drawn for each cheese (Fig. 4). The plots showed two distinct linear regions and the intersection point was identified as the melting point of fats in the cheese [26]. No significant difference was observed between the data obtained with the two methods. Indeed, the application of the Student test did not show difference between the results obtained with the two methods at a level effect of $5 \%$.

Considering the investigated temperature range, melting temperatures obtained with the two methods allow mainly the investigation of fat melting in cheese. The similar melting temperatures derived from rheological and fluorescence data also sug-
Table III. Evaluation of the melting temperatures of fat in cheeses using rheological data and fluorescence spectra.

\begin{tabular}{llllllll}
\hline \multicolumn{6}{c}{ Melting temperature $\left({ }^{\circ} \mathrm{C}\right)$} \\
\hline \multicolumn{5}{c}{ Rheological data } & \multicolumn{4}{l}{ Fluorescence data } \\
\hline Cheese & Mean & $\mathrm{SD}^{*}$ & $\mathrm{CV}^{*}$ & Mean & $\mathrm{SD}^{*}$ & $\mathrm{CV}^{*}$ \\
Emmental & 29.45 & 0.20 & 0.69 & 30.41 & 0.77 & 2.53 \\
Comté & 31.20 & 0.62 & 2.00 & 32.44 & 1.35 & 4.16 \\
Raclette & 31.79 & 1.22 & 3.85 & 31.27 & 0.31 & 1.00 \\
\hline
\end{tabular}

* SD: standard deviation. $\mathrm{CV}=100 \times(\mathrm{SD} /$ mean $)$. Reported melting temperatures are the means of five measurements (rheology) or three measurements (fluorescence).

gest that there was a relation between the structure of the cheese at the molecular level as investigated by fluorescence spectroscopy, and the texture determined using dynamic testing rheology measurements. 


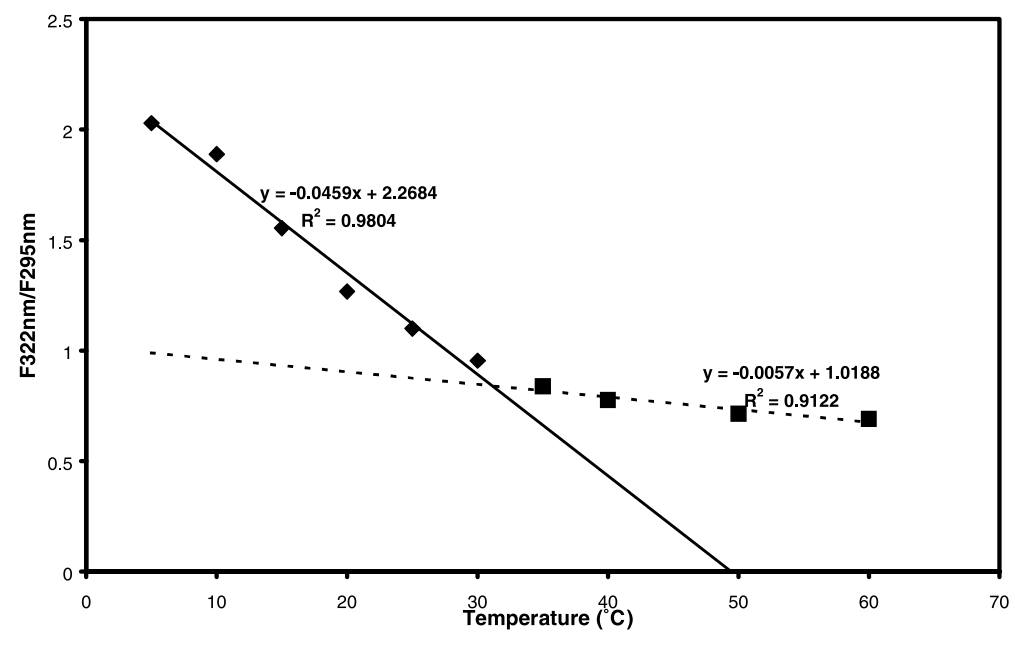

Figure 4. Determination of the melting point of Emmental cheese from the fluorescence spectra of vitamin A.

\subsection{Canonical correlation analysis of fluorescence and rheological data sets}

The possible correlations between the rheological data $\left(G^{\prime}, G^{\prime \prime}, \tan \delta\right.$, strain and $\left.\eta^{*}\right)$ and the fluorescence spectra (tryptophan and vitamin A) were investigated in order to get a better insight into the relationships between the characteristics at macroscopic and molecular levels of the investigated cheeses. For the CCA analysis, the rheological parameters and the fluorescence spectra recorded at the same temperatures, i.e., 5, 10, 15, 20, 25, 30, 35, 40,50 and $60{ }^{\circ} \mathrm{C}$ were considered. It has been successfully applied to comparing fluorescence and mid-infrared spectra of semi-hard cheeses [12] and rheology data and sensory data of Salers cheese [24]. In both cases, the authors were able to provide relevant similarity maps of the samples that were not immediately found by principal component analysis. From the presented data, it appeared that tryptophan fluorescence spectra and vitamin A spectra were highly correlated with the rheological data. Considering the fluorescence spectra of tryptophan and rheology data, the first two pairs of canonical variates were correlated, with their squared canonical correlation coefficients were equal to 0.94 and 0.60 . CCA applied to the fluorescence spectra of vitamin A and rheology data showed that the first two pairs of canonical variates were correlated since that their squared canonical correlation coefficients equal to 0.97 and 0.49 . Since the $P$-values of the first two pairs of canonical variates were lower than 0.05 , the considered data sets had statistically significant correlations at the $95 \%$ confidence level (data not shown). It indicated that a common description of the samples was possible both from the fluorescence and rheological data. The similarity maps for the CCA analysis performed on vitamin A spectral data and the rheological data are shown in Figures 5A-B. These figures show that the first canonical variates discriminated the data according to temperature. Indeed, the data recorded at temperatures below $20^{\circ} \mathrm{C}$ had positive scores according to the first canonical variate. Similar results were obtained for the CCA analysis performed on the tryptophan spectral data and the rheological data (data not shown). 

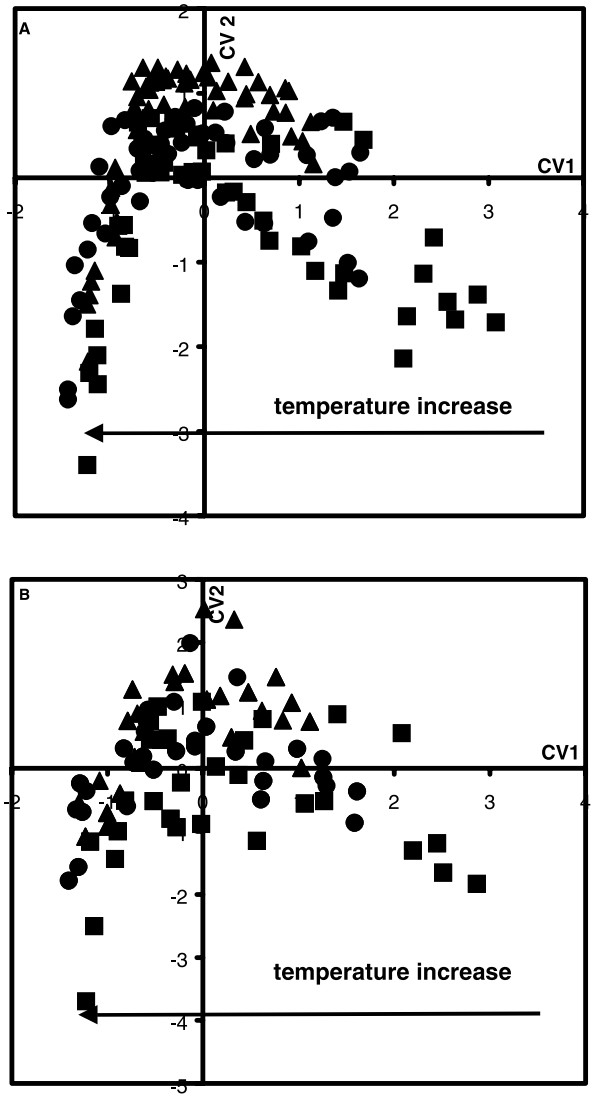

Figure 5. CCA applied to the vitamin A spectral data and the rheology data. (A) Similarity map defined by the canonical variates 1 and 2 for the rheology data. (B) Similarity map defined by canonical variates 1 and 2 for the vitamin A fluorescence spectral data: (ム): Raclette; $(\bullet)$ : Comté; (घ): Emmental.

As the two methods allowed the discrimination of the three cheeses during melting, it is suggested that the changes in the shape of fluorescence spectra were related to the changes in the cheese matrix structure induced by the increase of temperature. Indeed, during the temperature increase, the interactions between the protein network and the fat globules varied, depending on the temperature. Fusion of the triglycerides during the increase in temperature altered simultaneously the shape of vitamin A spectra and of tryptophan spectra. Our data strongly suggest that the structure and the interactions of micelles and fat globules, as investigated by fluorescence spectroscopy, determined the cheese texture. So, the phenomena observed at the molecular and macroscopic levels were related to the changes in the texture of the cheeses during melting.

\section{CONCLUSION}

This study shows that dynamic testing rheology measurements and fluorescence spectroscopy can be useful for monitoring the change in the texture and in the structures at the macroscopic and molecular levels, and for the determination of the melting point of cheeses and cheese fats during a temperature increase. The tryptophan and vitamin A fluorescence spectra of cheeses were fingerprints that allowed identification of the investigated cheeses. Rheological parameters such as the storage modulus ( $\left.G^{\prime}\right)$, loss modulus ( $\left.G^{\prime \prime}\right)$, $\tan \delta$ and the strain could be used to explain structural characteristics and changes in the 5$60{ }^{\circ} \mathrm{C}$ temperature range. Applying CCA to the rheological data and fluorescence spectra can provide different information related to the physical state of the fats, the structure of the cheese matrix and the change in the texture of cheeses during an increase in the temperature. The understanding of cheese rheological properties as a function of temperature is very important, since cheese is more and more often used as an ingredient for the manufacturing of elaborate food products.

Spectroscopic methods have been used for a long time to determine the chemical composition of foodstuffs. It is shown in this study that quality parameters of cheeses, such as rheology attributes, may be derived from fluorescence data. Fluorescence has the same potential to address problems in food science as in biochemical 
science, because the scientific questions requiring answers are closely related.

\section{REFERENCES}

[1] Ak M.M., Gunasekaran S., Stress-strain curve analysis of Cheddar cheese under uniaxial compression, J. Food Sci. 57 (1992) 1078-1081.

[2] Arnott D.R., Morris H.A., Combs W.B., Effects of certain chemical factors on the melting quality of process cheese, J. Dairy Sci. 40 (1957) 957-963.

[3] Bertola N.C., Bevilacqua A.E., Zaritzky N.E., Proteolytic and rheological evaluation of maturation of Tybo Argentino cheese, J. Dairy Sci. 75 (1992) 3273-3281.

[4] Bertrand D., Scotter C.N.G., Application of multivariate analyses to NIR spectra of gelatinized starch, Appl. Spectrosc. 46 (1992) 1420-1425.

[5] Bouton Y., Guyot P., Dasen A., Grappin R., Activité protéolytique de souches de lactobacilles thermophiles isolées de levains et de Comté. II - Applications en sites industriels, Lait 74 (1994) 33-46.

[6] Bowland E.L., Foegeding E.A., Small strain oscillatory shear and microstructural analyses of a model processed cheese, J. Dairy Sci. 84 (2001) 2372-2380.

[7] Bugaud C., Buchin S., Noël Y., Tessier L., Pochet S., Martin B., Chamba J.F., Relationships between Abondance cheese texture, its composition and that of milk produced by cows grazing different types of pastures, Lait 81 (2001) 593-607.

[8] Campanella O.H., Popplewell L.M., Rosenau J.R., Peleg M., Elongational viscosity measurements of melting American process cheese, J. Food Sci. 52 (1987) 1249-1251.

[9] Chamba J.F., Delacroix-Buchet A., Berdagué J.L., Clement J.F., Une approche globale de la caractérisation des fromages : l'exemple $\mathrm{du}$ fromage Beaufort, Sci. Aliments 14 (1994) 581-590.

[10] Dufour E., Riaublanc A., Potentiality of spectroscopic methods for the characterisation of dairy products. I. Front-face fluorescence study of raw, heated and homogenised milks, Lait 77 (1997) 657-670.

[11] Dufour E., Lopez C., Riaublanc A., Mouhous Riou N., La spectroscopie de fluorescence frontale : une approche non invasive de la structure et des interactions entre les constituants des aliments, Agoral 10 (1998) 209-215.

[12] Dufour E., Mazerolles G., Devaux M.F., Duboz G., Duployer M.H., Mouhous Riou N., Phase transition of triglycerides during semi-hard cheese ripening, Int. Dairy J. 10 (2000) 87-99.

[13] Famelart M.-H., Le Graet Y., Michel F., Richoux R., Riaublanc A., Évaluation des méthodes d'appréciation des propriétés fonctionnelles des fromages d'Emmental de l'Ouest de la France, Lait 82 (2002) 225-245.

[14] Genot C., Tonetti F., Montenay-Garestier T., Marion D., Drapon R., Front-face fluorescence applied to structural studies of proteins and lipid-protein interactions of visco-elastic food products. 2. Application to wheat gluten, Sci. Aliments 12 (1992) 687-704.

[15] Herbert S., Caractérisation de la structure moléculaire et microscopique de fromages à pâte molle. Analyse multivariée des données structurales en relation avec la texture, Thèse, École Doctorale Chimie Biologie de l'Université de Nantes, France, 1999.

[16] Herbert S., Riaublanc A., Bouchet B., Gallant D.J., Dufour E., Fluorescence spectroscopy investigations of acid- and rennet-induced milk coagulations of milk, J. Dairy Sci. 82 (1999) 2056-2062.

[17] Herbert S., Mouhous Riou N., Devaux M.F., Riaublanc A., Bouchet B., Gallant J.D., Dufour E., Monitoring the identity and the structure of soft cheeses by fluorescence spectroscopy, Lait 80 (2000) 621-634.

[18] Horne D.S., Banks J.M., Leaver J., Law A.J.R., Dynamic mechanical spectroscopy of Cheddar cheese, in: Cheese yield and factors affecting its control, Int. Dairy Fed., Brussels, Belgium, special issue 9402 (1994) 507-512.

[19] Jaros D., Ginzinger W., Tschager E., Mayer H.K., Rhom H., Effect of water addition on composition and fracture properties of Emmental cheese, Lait 77 (1997) 467-477.

[20] Jollife I.T., Principal Component Analysis, Springer, New York, USA, 1986.

[21] Klantschitsch T., Bachmann H.P., Puhan Z., Influence of milk treatment and ripening conditions on quality of Raclette cheese, Lait 80 (2000) 51-67.

[22] Konstance R.P., Holsinger V.H., Development of rheological test methods for cheese, Food Technol. 1 (1992) 105-109. 
[23] Kuo M.-I., Wang Y.-C., Gunasekaran S., A viscoelasticity index for cheese meltability evaluation, J. Dairy Sci. 83 (2000) 412-417.

[24] Lebecque A., Laguet A., Devaux M.F., Dufour E., Delineation of the texture of Salers cheese by sensory analysis and physical methods, Lait 81 (2001) 609-623.

[25] Lee C.H., Imoto E.M., Rha C., Evaluation of cheese texture, J. Food Sci. 43 (1978) 1600-1605.

[26] Lopez C., Influence de la nature de l'interface matière grasse/eau de laits reconstitués sur la cinétique de coagulation et les caractéristiques du coagulum, Stage de DEA, Université de Bordeaux, France, 1997.

[27] Mac Gibbon A.K.H., McLennan WD., Hardness of New Zealand patted butter: seasonal and regional variations, J. Dairy Sci. Technol. 22 (1987) 143-156.

[28] Mazerolles G., Devaux M.F., Duboz G., Duployer M.H., Mouhous Riou N., Dufour E., Infrared and fluorescence spectroscopy for monitoring protein structure and interaction changes during cheese ripening, Lait 81 (2001) 509-527.
[29] Muthukumarappan K., Wang Y.-C., Gunasekaran S., Estimating softening point of cheeses, J. Dairy Sci. 82 (1999) 2280-2286.

[30] Rosenberg M., Wang Z., Chuang S.L., Shoemaker C.F., Viscoelastic property changes in Cheddar cheese during ripening, J. Food Sci. 60 (1995) 640-644.

[31] Ruegg M., Eberhard P., Popplewell M., Peleg M., Melting properties of cheeses, Int. Dairy Fed. Bull. 268 (1991) 36-43.

[32] Saporta G., Probabilités - Analyse des données et statistique, Technip édn., Paris, 1990.

[33] Shoemaker C.F., Nantz J., Bonnans S., Noble A.C., Rheological characterization of dairy products, J. Food Technol. 46 (1992) 98-104.

[34] Vassal L., Monnet V., Le Bars D., Roux C., Gripon J.C., Relation entre le $\mathrm{pH}$, la composition chimique et la texture des fromages de type Camembert, Lait 66 (1986) 341-351.

[35] Visser J., Factors affecting the rheological and fracture properties of hard and semihard cheese, Int. Dairy Fed. Bull. 268 (1991) 49-61. 